\title{
Financial Management of Pharmacies in the City of Cabanatuan, Philippines
}

\author{
Alvin Gino M. Bautista
}

\begin{abstract}
This research was made to determine the effectiveness of selected small-scale pharmacy store owners in Cabanatuan City, Philippines in terms of their financial management that will focus on cash and accounts payable management. It involved 16 small-scale pharmacy businesses operating near the government hospitals in Cabanatuan City such as Dr. Paulino J. Garcia Memorial Research Center, Manuel V. Gallego, Cabanatuan City Hospital, and Eduardo L. Joson Provincial Hospital. These Small-Scale Pharmacy Business includes sole proprietorships and partnership type of business, Other pharmacy stores located in the same area were not included because they belong to the corporate type of business.

The outcome of this research will be useful and valuable to the Small-Scale Pharmacy Store owners and it will provide necessary pieces of information about management styles which could be of significant help to the smallscale pharmacy store owners. It can also help them to be more efficient in handling their cash and accounts payable through the help of the recommendation by the researcher. To the Product Suppliers, the outcome of this study will be helpful to the suppliers of different small-scale pharmacy stores in the matter of mode of payment and incentives given to the owners which are most important to motivate them to sell more. To the Investors, the results of this study can help investors who want to have a small-scale pharmacy store in terms of cash and payable handling and dealing with problems that their business might encounter. To the Philippine Economy, the results of this study will strengthen and back up the economy of the Country. Since the study aims to evaluate the business profile of the small-scale pharmacy store owners including managing their working capital, it also includes the evaluation of the competitiveness of their business. This only means that the study wishes to find out more about the nature of the existence of the said enterprises as well as their relationship to their suppliers and customers. Lastly, this will also be beneficial to future researchers to draw pertinent results to their studies.
\end{abstract}

The researcher also wishes to evaluate the literacy of selected small-scale pharmacy businesses within the City of Cabanatuan, Philippines along with the areas of cash management and accounts payable management using the descriptive method of research.

Keywords - Pharmacy, Financial Management, Cash Management, Accounts Payable Management, SmallScale Businesses.

\section{INTRODUCTION}

A community pharmacy or drug store is one of the most constant industries in the Philippines because medicine is essential nowadays, and demand uninterruptedly increases as the population continuously increasing. The majority of those who go into this business are pharmacists or doctors because they know a lot about medicine, but because business is open for everybody, whoever wants to establish this kind of business can create one as long as they will follow the rules and regulations provided by the Philippines law.
The State recognizes the vital role of pharmacists in the delivery of quality health care services through the provision of safe, effective, and quality pharmaceutical products, pharmaceutical care, drug information, patient medication counseling, and health promotion. The pharmacists' professional services shall, therefore, be promoted as an indispensable component of the total health care system to ensure the physical well-being of the Filipinos. (Section 2 of RA. 10918)

Small scale enterprises $\mathrm{s}$ are privately owned sole proprietorships or partnerships, that have fewer employees 
and/or less annual revenue than a regular-sized business or corporation. Small businesses are either services or retail operations like grocery stores, medical stores, tradespeople, bakeries, and small manufacturing units. Small businesses are independently owned organizations that require less capital and less workforce and less or no machinery. These businesses are ideally suited to operate on a small scale to serve a local community and to provide profits to the company owners.

Cash management is a terrifying thing for any enterprise to regulate. Inappropriate cash management can lead to unnecessary debt or even insolvency. The absence of cash management can put small-scale businesses out of business, it is because they do not have well cash management. Absence of cash management system or at least carefully monitoring cash, a business can become nonsolvent very fast because they do not have existing cash for regular or unexpected expenses. Many small Pharmacy businesses struggle with cash management because they are reliant on sales and on-time payments. It is comparable to the personal financial problem of living paycheck to paycheck, with nothing available from week to week.

Accounts payable and its administration is vital for the smooth operational procedure of any business entity. It is significant for any business because it mostly takes the responsibility of disbursing the entity's bills on a timely basis. This is necessary so that solid credit and long-term affairs with the suppliers can be continued. Only when bills are paid on time, sellers will safeguard a continuous flow of supplies and services; which in turn will aid in the systematic flow of the enterprise. A good accounts payable procedure ensures there are no late responsibilities, penalty or late charges to be paid for the dues. The prepared accounts payable procedure ensures all that the bills due are traced and paid correctly. This will help avoid lost expenditures and making a payment double. It also allows businesses to accomplish improved cash flows. Frauds and thefts can be away from to a superior extent by following strict accounts payable procedures.

The problem which the researcher wishes to study is about the condition of the Pharmacy Store Business which are considered as the micro, small and medium enterprises that are protected by Republic Act 10918 - An Act Regulating and Modernizing the Practice of Pharmacy in the Philippines. And Republic Act 5921 - An Act Regulating the Practice of Pharmacy and Setting Standards of Pharmaceutical Education in The Philippines and for Other Purposes. The researcher also wishes to evaluate the literacy of selected small-scale pharmacy businesses within the City of Cabanatuan along with the areas of cash management and accounts payable management.

\section{OBJECTIVES OF THE STUDY}

The research was made to determine the effectiveness of selected small-scale pharmacy store owners in Cabanatuan City in terms of their financial management that will focus on cash and accounts payable management.

The objective of this research is sought to answers the following questions:

1. How may the business profile of the selected smallscale pharmacy store owner- respondents be described in terms of:

1.1 Types of Business Ownership

1.2 Year Established

1.3 Number of Years in Business

1.4 Numbered of Registered Pharmacist Employed

1.5 Number of Pharmacy Assistant Employed

1.6 Type of Store Ownership

1.7 Terms of Payment to the Suppliers

1.8 Incentives from the Suppliers
1.8.1 Discounts
1.8.2 Commission
1.8.3 Vacation

2. Describe the working capital of small-scale pharmacy business in terms of:

2.1 Cash

2.2 Accounts Payable

3. What are the problems encountered by the Pharmacy store owners with their:

3.1 Suppliers

3.2 Customers

4. Impact of the study of the small-scale pharmacy to the following:

4.1 Owners

4.2 Suppliers

\section{METHODOLOGY}

The researcher used the Descriptive Survey Method of research. The study wishes to find out and describe the present profile of the business of selected small-scale pharmacy businesses within Cabanatuan City, Philippines; 
their efficiency in financial management in terms of cash, and their accounts payable.

The study involved all the owners of selected smallscale pharmacy business near the surrounding of Government Hospitals located in Cabanatuan City. There are 3 Government Hospitals in the City of Cabanatuan such as Paulino J. Garcia Memorial Research Medical Center, located at Mabini cor Gen. Tinio St, Cabanatuan City. Manuel V. Gallego Cabanatuan City Hospital located at PanPhilippine Hwy, Zulueta, Cabanatuan City, Nueva Ecija. Eduardo L. Joson Memorial Hospital (Nueva Ecija Provincial Hospital), located at Pan-Philippine Highway, Daang Sarile, Cabanatuan City, Nueva Ecija.

The researcher used a set of survey questionnaires to gather pertinent data. The interview will also be used to clarify aspects that will not be able to discuss satisfactorily by the questionnaire. The questionnaire was constructed by the researcher through their review of related literature.

\section{RESULTS AND DISCUSSION}

\subsection{Profile of the Business}

Table 1 Type of Business

\begin{tabular}{|l|c|c|}
\hline Type of Business & Frequency & Percentage \\
\hline Sole Proprietorship & 13 & $81 \%$ \\
\hline Partnership & 3 & $19 \%$ \\
\hline Total & 16 & $100 \%$ \\
\hline
\end{tabular}

Table 1 shows a total of 16 small-scale pharmacies were surveyed and based on the result, 13 or $81 \%$ are Sole Proprietorships and 3 out of 16 or $19 \%$ are Partnership. It means that the majority of the Small-Scale Pharmacy Businesses operating in the area were Sole Proprietorship.

Table 2. Number of Years in the Business

\begin{tabular}{|l|c|c|}
\hline \multicolumn{1}{|c|}{ Years } & Frequency & Percentage \\
\hline $0-5$ years & 6 & $38 \%$ \\
\hline $6-10$ years & 3 & $19 \%$ \\
\hline $11-15$ years & 3 & $19 \%$ \\
\hline $16-20$ years & 1 & $6 \%$ \\
\hline $21-25$ years & 2 & $13 \%$ \\
\hline
\end{tabular}

\begin{tabular}{|l|c|c|}
26 and above & 1 & $6 \%$ \\
years & 16 & $100 \%$ \\
\hline Total & 16 & \\
\hline
\end{tabular}

The number of years in the business of the pharmacies shows in Table 2 means $38 \%$ are $0-5$ years, $19 \%$ are $6-10$ years, $19 \%$ are $11-15$ years, $6 \%$ are $16-20$ years, $13 \%$ are $21-25$ years, and $6 \%$ are 26 years and above. It means many of the respondents were in the star-up stage of the business.

Table 3 Number of Registered Pharmacist Employed

\begin{tabular}{|c|c|c|}
\hline $\begin{array}{l}\text { Pharmacist } \\
\text { Employed }\end{array}$ & Frequency & Percentage \\
\hline $\begin{array}{c}\text { 1 Registered } \\
\text { Pharmacist }\end{array}$ & 15 & $94 \%$ \\
\hline $\begin{array}{c}\text { 2 Registered } \\
\text { Pharmacist }\end{array}$ & 1 & $6 \%$ \\
\hline Total & 16 & $100 \%$ \\
\hline
\end{tabular}

Based on the survey conducted by the researcher, Table 3 shows that $94 \%$ of the respondents employed 1 registered pharmacist and 6\% employs 1 registered pharmacist. It simply means that all respondents employed a pharmacist in obedience to the Republic act no. 5921. an act regulating the practice of pharmacy and setting standards of pharmaceutical education in the Philippines and for other purposes.

Table 4 Number of Pharmacy Assistant Employed

\begin{tabular}{|c|c|c|}
\hline $\begin{array}{c}\text { Number of Pharmacy } \\
\text { Assistant Employed }\end{array}$ & Frequency & Percentage \\
\hline 1 Pharmacy Assistant & 3 & $19 \%$ \\
\hline 2 Pharmacy Assistant & 5 & $31 \%$ \\
\hline 3 Pharmacy Assistant & 1 & $6 \%$ \\
\hline 4 Pharmacy Assistant & 4 & $25 \%$ \\
\hline 5 Pharmacy Assistant & 1 & $6 \%$ \\
\hline $\begin{array}{c}\text { A and above Pharmacy } \\
\text { Assistant }\end{array}$ & 2 & $13 \%$ \\
\hline Total & 16 & $100 \%$ \\
\hline
\end{tabular}

Table 4 shows that $19 \%$ of the small-scale pharmacies employ 1 pharmacy assistant, 31\% employs 2, 6\% employs $3,25 \%$ employs $4,6 \%$ employs 5 , and $13 \%$ employs 6 and above pharmacy assistants. 
Table 5 Type of Store Ownership

\begin{tabular}{|l|c|c|}
\hline $\begin{array}{l}\text { Type of Store } \\
\text { Ownership }\end{array}$ & Frequency & Percentage \\
\hline Owned & 2 & $12 \%$ \\
\hline Rented & 14 & $88 \%$ \\
\hline Total & 16 & $100 \%$ \\
\hline
\end{tabular}

Table 5 shows the frequency and percentage among the 16 respondents of small-scale pharmacy stores, reveals that $88 \%$ were renting their store and $13 \%$ owned their store. The majority of the respondents have a rental expense that can be deducted from their monthly income.

Table 6 Type of Payment to the Suppliers

\begin{tabular}{|l|c|c|}
\hline $\begin{array}{c}\text { Type of Payment to } \\
\text { the Suppliers }\end{array}$ & Frequency & Percentage \\
\hline Cash Only & 2 & $13 \%$ \\
\hline Cash and Check & 12 & $75 \%$ \\
\hline $\begin{array}{l}\text { Cash, Check, and Bank } \\
\text { Transfer }\end{array}$ & 2 & $13 \%$ \\
\hline Total & 16 & $100 \%$ \\
\hline
\end{tabular}

Table 6 shows that $13 \%$ of the Pharmacies used only cash in paying their suppliers, $75 \%$ were using cash and checks, and $13 \%$ were using Cash, Checks, and Bank Transfer Services.

Table 7 Terms of Payment if Purchased on Credit

\begin{tabular}{|l|c|c|}
\hline $\begin{array}{c}\text { Terms of payment } \\
\text { if purchase on } \\
\text { credit to the } \\
\text { suppliers }\end{array}$ & Frequency & Percentage \\
\hline 15 days & 1 & $6 \%$ \\
\hline 30 days & 9 & $56 \%$ \\
\hline 60 days & 2 & $13 \%$ \\
\hline 90 days & 4 & $25 \%$ \\
\hline Total & 16 & $100 \%$ \\
\hline
\end{tabular}

The payment of consigned goods has a specific term which the owner needs to pay the supplier. $6 \%$ of small-scale pharmacy stores received terms of payment to the suppliers of 15 days, $56 \%$ received 30 days, $13 \%$ received 60 days, and $25 \%$ received 90 days.

\section{FINANCIAL MANAGEMENT OF PHARMACY BUSINESS OWNERS}

A. Cash Management

Table 8 Monthly Income

\begin{tabular}{|l|c|c|}
\hline $\begin{array}{l}\text { Does the business have } \\
\text { a monthly income? }\end{array}$ & Frequency & Percentage \\
\hline Seldom & 1 & $6 \%$ \\
\hline Occasionally & 3 & $19 \%$ \\
\hline Sometimes & 4 & $25 \%$ \\
\hline Always & 8 & $50 \%$ \\
\hline Total & 16 & $100 \%$ \\
\hline
\end{tabular}

To have an income is the number 1 goal of every business, thus, Table 8 shows respondents who answered the question if they have a monthly income which reveals $6 \%$ answered Seldom, 19\% answered Occasionally, 25\% answered Sometimes, and $50 \%$ answered they had a monthly income from their business.

Table 9 Monthly Bank Deposits

\begin{tabular}{|l|c|c|}
\hline $\begin{array}{c}\text { Does the business } \\
\text { have a monthly } \\
\text { deposit on its bank } \\
\text { account? }\end{array}$ & Frequency & Percentage \\
\hline Never & 1 & $6 \%$ \\
\hline Occasionally & 3 & $19 \%$ \\
\hline Sometimes & 3 & $19 \%$ \\
\hline Always & 9 & $56 \%$ \\
\hline Total & 16 & $100 \%$ \\
\hline
\end{tabular}

Sales or Income of the business must be deposited to the bank for safekeeping, thus, Table 9 reveals $6 \%$ of the respondents answered Never or they have no monthly deposit on their bank account, 19\% answered they deposit Occasionally, 19\% answered they deposit Sometimes, and the majority of the respondents answered they Always deposit on their bank accounts. 
Table 10 Withdrawal for Personal Use

\begin{tabular}{|l|c|c|}
\hline $\begin{array}{c}\text { Withdrawal from } \\
\text { the business for } \\
\text { personal use? }\end{array}$ & Frequency & Percentage \\
\hline Never & 5 & $31 \%$ \\
\hline Seldom & 2 & $13 \%$ \\
\hline Occasionally & 3 & $19 \%$ \\
\hline Sometimes & 4 & $25 \%$ \\
\hline Always & 2 & $13 \%$ \\
\hline Total & 16 & $100 \%$ \\
\hline
\end{tabular}

The money of the business must be separated from the personal money of the owner, thus, Table 10 shows, $31 \%$ responded Never, 13\% responded Seldom, 19\% responded Occasionally, 25\% responded Sometimes, and 13\% answered Always.

Table 11 Use of Check or Bank Services in Paying their Suppliers

\begin{tabular}{|l|c|c|}
\hline $\begin{array}{l}\text { Use of check or } \\
\text { bank services in } \\
\text { paying their } \\
\text { suppliers? }\end{array}$ & Frequency & Percentage \\
\hline Never & 2 & $13 \%$ \\
\hline Seldom & 3 & $19 \%$ \\
\hline Occasionally & 1 & $6 \%$ \\
\hline Always & 10 & $63 \%$ \\
\hline Total & 16 & $100 \%$ \\
\hline
\end{tabular}

To avoid theft, payment using physical money, and to avoid having counterfeit money, checks and other bank services were available that is suitable in all businesses, thus, $13 \%$ of the respondents Never used check or other services in paying their suppliers, 19\% used it Seldom, 6\% used it Occasionally, and the majority or the $63 \%$ used the service of the bank Always.
Table 12 Use of Accounting Software

\begin{tabular}{|l|c|c|}
\hline $\begin{array}{l}\text { Does the business } \\
\text { use procedure or } \\
\text { accounting software } \\
\text { in handling their } \\
\text { cash, and payables? }\end{array}$ & Frequency & Percentage \\
\hline Never & 14 & $88 \%$ \\
\hline Always & 2 & $13 \%$ \\
\hline Total & 16 & $100 \%$ \\
\hline
\end{tabular}

Accounting software benefits include increased accuracy by reducing or eliminating human errors in calculation. Manual bookkeeping processes involve making a lot of mathematical calculations by hand. An incorrect calculation early on the process could have a great impact on the end balance. (A.Walton, 2019) Thus, the question, "Does the business use procedure or accounting software in handling their cash, and payables?", 88\% responded Never, while the minority composed of $12 \%$ answered they used it Always.

Table 13 Cash Management Literacy

\begin{tabular}{|l|c|c|}
\hline $\begin{array}{l}\text { How well do you } \\
\text { know Cash } \\
\text { Management? }\end{array}$ & Frequency & Percentage \\
\hline Very Well & 4 & $25 \%$ \\
\hline Minimal Idea & 10 & $63 \%$ \\
\hline No Idea & 2 & $13 \%$ \\
\hline Total & 16 & $100 \%$ \\
\hline
\end{tabular}

With regards to Cash Management Literacy of the smallscale pharmacy store owners, $63 \%$ of the respondents answered they have a Minimal Idea about cash management, $25 \%$ of the respondents answered they have a Very Well understanding about it, and the remaining $12 \%$ answered they have No Idea about Cash Management. 


\section{B. ACCOUNTS PAYABLE MANAGEMENT}

Table 14 Suppliers Who Give Product for Consignment

\begin{tabular}{|l|c|c|}
\hline $\begin{array}{c}\text { Is there a } \\
\text { supplier who } \\
\text { gives products } \\
\text { for } \\
\text { consignment? }\end{array}$ & Frequency & Percentage \\
\hline Seldom & 3 & $19 \%$ \\
\hline Occasionally & 1 & $6 \%$ \\
\hline Sometimes & 7 & $44 \%$ \\
\hline Always & 5 & $31 \%$ \\
\hline Total & 16 & $100 \%$ \\
\hline
\end{tabular}

Consignment is common in pharmacy business, and this method is good for the consignor as well as to the consignee, thus, Table 14 reveals $19 \%$ of the responded answered they received products for consignment from their supplier Seldomly, 6\% answered Occasionally, 44\% answered Sometimes, and $31 \%$ answered they Always received a consigned medicine.

Table 15 On-time Payment to Supplier

\begin{tabular}{|l|c|c|}
\hline $\begin{array}{c}\text { Does the business } \\
\text { pay its supplier on } \\
\text { time? }\end{array}$ & Frequency & Percentage \\
\hline Occasionally & 1 & $6 \%$ \\
\hline Sometimes & 2 & $13 \%$ \\
\hline Always & 13 & $81 \%$ \\
\hline Total & 16 & $100 \%$ \\
\hline
\end{tabular}

It appears in Table 15 that $6 \%$ of the respondents answered they pay their supplier on-time Occasionally, $19 \%$ pays Sometimes, and $81 \%$ Always pay on time.

Table 16 Supplier's Discount, Commissions, and Incentives

\begin{tabular}{|l|c|c|}
\hline $\begin{array}{c}\text { Does the business } \\
\text { have a past due } \\
\text { accounts with the } \\
\text { suppliers? }\end{array}$ & Frequency & Percentage \\
\hline Never & 6 & $38 \%$ \\
\hline Seldom & 3 & $19 \%$ \\
\hline
\end{tabular}

\begin{tabular}{|l|c|c|} 
Occasionally & 2 & $13 \%$ \\
\hline Sometimes & 5 & $31 \%$ \\
\hline Total & 16 & $100 \%$ \\
\hline
\end{tabular}

Past due accounts must be avoided by all the businesses because it will create another expense, thus, Table 16 shows 38\% responded Never, 19\% answered Seldom, 13\% responded Occasionally, and 31\% responded Sometimes.

Table 17 Monthly Interest Payable with the Suppliers

\begin{tabular}{|l|c|c|}
\hline $\begin{array}{c}\text { Monthly interest } \\
\text { payable with the } \\
\text { suppliers? }\end{array}$ & Frequency & Percentage \\
\hline Never & 12 & $75 \%$ \\
\hline Seldom & 2 & $13 \%$ \\
\hline Always & 2 & $13 \%$ \\
\hline Total & 16 & $100 \%$ \\
\hline
\end{tabular}

With regards to interest payable, $75 \%$ of the respondents answered they Never have an interest payable, $13 \%$ answered Seldom, and another $13 \%$ answered Always.

Table 18 Aging of Accounts Payable

\begin{tabular}{|l|c|c|}
\hline $\begin{array}{c}\text { Does the } \\
\text { business use } \\
\text { aging of } \\
\text { accounts } \\
\text { payable? }\end{array}$ & Frequency & Percentage \\
\hline Never & 8 & $50 \%$ \\
\hline Seldom & 2 & $13 \%$ \\
\hline Occasionally & 1 & $6 \%$ \\
\hline Sometimes & 3 & $19 \%$ \\
\hline Always & 2 & $13 \%$ \\
\hline Total & 16 & $100 \%$ \\
\hline
\end{tabular}

Table 16 reveals 50\% answered they Never used it, 13\% answered Seldom, 6\% answered, Occasionally, 19\% answered Sometimes, and 13\% Always use it. 
Table 19 Accounts Payable Management Literacy

\begin{tabular}{|l|c|c|}
\hline $\begin{array}{l}\text { How well do you } \\
\text { know Accounts } \\
\text { Payable } \\
\text { Management? }\end{array}$ & Frequency & Percentage \\
\hline Very Well & 6 & $38 \%$ \\
\hline Minimum Idea & 8 & $50 \%$ \\
\hline No Idea & 2 & $13 \%$ \\
\hline Total & 16 & $100 \%$ \\
\hline
\end{tabular}

Table 17 shows Most of the respondents answered they have a Minimal Idea about it and it represents $50 \%$ of the total respondents, 38\% answered they knew it Very Well, and $12 \%$ answered they have No Idea about accounts payable management.

\section{The Problems Encountered by the Small-Scale Pharmacy Business Owners}

Table 20 Problem Encountered with the suppliers

\begin{tabular}{|l|c|c|}
\hline $\begin{array}{c}\text { The Problems Encountered } \\
\text { by the Small-Scale Pharmacy } \\
\text { Business Owners with their } \\
\text { Suppliers }\end{array}$ & $\begin{array}{c}\text { Weighted } \\
\text { Mean }\end{array}$ & Rank \\
\hline Hard to contact & 1.75 & 1 \\
\hline Always lack of supplies & 2.06 & 2 \\
\hline Supplying poor quality & 3.06 & 3 \\
\hline $\begin{array}{l}\text { Not committing on their } \\
\text { promise }\end{array}$ & 3.44 & 4 \\
\hline Cannot deliver on time & 4.69 & 5 \\
\hline
\end{tabular}

The top problem encountered by the small-scale pharmacy business owners is the suppliers that cannot deliver the products on time, followed by Suppliers who are not committing with their promises, then the suppliers which are hard to contact, next was Always lack of supplies, and the least was Supplying poor quality.

Table 21 Problem Encountered with the clients

However, the top problem that the small-scale pharmacy business encountered with their clients based on the survey conducted by the researcher was, Clients who are not bringing their prescription, followed by clients who don't know what is the name of the medicine and dosage needed,

\begin{tabular}{|l|c|c|}
\hline $\begin{array}{c}\text { The Problems Encountered by the } \\
\text { Small-Scale Pharmacy Business } \\
\text { Owners with their Clients }\end{array}$ & $\begin{array}{c}\text { Weighted } \\
\text { Mean }\end{array}$ & Rank \\
\hline Not bringing their prescription & 1.19 & 1 \\
\hline $\begin{array}{l}\text { They don't know what is the name } \\
\text { of the medicine and dosage needed }\end{array}$ & 2.75 & 2 \\
\hline $\begin{array}{l}\text { ID for senior citizen's and PWD } \\
\text { discount }\end{array}$ & 2.81 & 3 \\
\hline Irate clients & 3.50 & 4 \\
\hline Shop lifters & 4.75 & 5 \\
\hline
\end{tabular}

then ID for senior citizen's and PWD discount, next is Irate clients, and the list is the problem with the shoplifters.

\section{CONCLUSION AND RECOMMENDATIONS}

After a thorough gathering of data on the descriptive investigation, the researcher made an analysis of the financial management of small-scale pharmacy business in the City of Cabanatuan, Philippines. The researcher therefore concludes and recommends the following statements: the majority of the respondents are in sole proprietorship type of business, and most of them are in the start-up business, Start-up means a fledgling business enterprise (Merriam-Webster). So many startups fail within the first few years. That's why this initial period is so important. Entrepreneurs need to find money, create a business model and business plan, hire key personnel, work out intricate details such as equity stakes for partners and investors, and plan for the long run. Many of today's most successful companies began as startups. (M.Grant, 2020). The researcher recommends that they must be diligent in handling their income including their cash as well as their expenses together with their accounts payable.

Every pharmacy, drugstore or hospital pharmacy whether owned by the government or a private person or firm shall at all times when open for business be under the personal and immediate supervision of a registered pharmacist: Provided, that no pharmacist shall have personal supervision of more than one such establishment. In cases where a drug establishment operates in more than one shift, each shift must be under the supervision and control of a registered pharmacists. (R.A 5921, Sec 27.) The researcher concludes that all respondents abide by this law having proof that they employ at least 1 registered pharmacist that will supervise the pharmacy. It is recommended that although they were following this Act, it is better for them to study this more 
thoroughly for the betterment of their business and to have a harmonious relationship between them and the government agencies.

The majority of the respondents use cash, checks, and other bank services in paying their suppliers. It is good for the store owner to avoid counterfeit money and to safe keep their income. Not all of them have a monthly income, the researcher concludes that this is because they are new into the business and many are in the star-up stage. It is also noted that there were some large-scare pharmacies in the same area that is why competition is very tight. The researcher concludes that it is important for the business owner to have an understanding of the products of that bank that they can be used to have a smooth flow business. It is highly recommended to have a seminar for the small-scale pharmacy owner about the bank products and services.

There are many reasons why it is very important to separate the personal finance of the owners and their business finances such as 1 . The business is taxed differently from personal finance, 2 . This can permit the owner to know the financial performance of the business, 3 . If the money is not separated, then it might be problematic to audit when both finances combine. The researcher, therefore, concludes based on the survey conducted that many of them do not know how to separate business and personal finances. This is because only $31 \%$ of them answered they never get money from their business for personal use. And there were 13\% who get money from their business frequently and this is not good for the business. The researcher also concludes that most of the respondents have a Minimal Idea about Cash Management. It is highly recommended to have a seminar and training for the small-scale pharmacy owners about Cash Management Literacy to be conducted by different agencies like banks, colleges and universities, Department of Finance, Department of Trade and Industries, Bangko Sentral ng Pilipinas, and other financial institutions.

According to Kanya of hashmicro.com, "Nowadays, accounting software has become a vital need for any business. Business owners have started to realize that managing finances manually would not help them achieve the expected results. In many cases, financial management, which is supposed to be able to help companies manage their budgets more efficiently, has become one of the reasons for financial loss." Though this statement is current, the researcher presumed that accounting software was not their priority because it is too expensive and they were thinking that it is not necessary for their business. Though the researcher agrees that accounting software is too much for the respondents, it is still recommended to try free accounting software that can be downloaded on the internet like the following:

List of free accounting Software:

1. Wave,

2. Zipbooks,

3. Akaunting,

4. SlickPie,

5. GnuCash,

6. CloudBooks,

7. Zoho Invoice

8. NCH Express Accounts https://www.fundera.com/

Some suppliers gave consignment medicines and merchandise to the small-scale pharmacies. Based on the survey conducted, the researcher presumed that most of the respondents pay their suppliers on a timely basis which is very important to have a better connection between them. But there were times that they cannot pay on-time that is why they will get past due accounts and interest payable was automatically added to their expenses. The researcher also concludes that most of the respondents have a Minimal Idea about Accounts Payable Management. The researcher highly recommends to study or use the aging of accounts payable to know the length of time the invoice must be paid, and to avoid interest expense, and to get the cash ready for payment. It is also recommended to have a seminar about accounts payable management or it can be included as another part of the financial literacy seminar for small-scale pharmacy owners.

Based on the problems encountered by the business, the researcher concludes that it is not the poor quality of medicines was the main problem of the business but the suppliers that cannot deliver on time, this is because most of the suppliers are from Metro Manila and some part of the regions. However, their top problem with their clients was not the shoplifters but the clients who do not bring their prescriptions. The researcher concludes that prescription is very important to give the right medicines, dosage, and brands that were given by the physician.

As reiterated by the researcher, Financial Management Literacy Seminars and Training are highly recommended for the small-scale pharmacy owner of the City of Cabanatuan, Philippines. 


\section{REFERRENCES}

[1] Merriam Webster https://www.merriamwebster.com/dictionary/

[2] Official Gazette of the Philippines https://www.officialgazette.gov.ph/2016/07/21/republic-actno-10918/

[3] Kieth N. Herist, Brent Rollins and Matthew Perri III 2011 Financial Analysis in Pharmacy Practice, 1 Lambeth High Street, London SE1 7JN, UK 1559 St. Paul Avenue, Gurnee, IL 60031, USA

[4] James A. Jorgenson, RPh, MS, FASHP (2013); The Business of Pharmacy: A Prescription for Change Copyright Pharmacy Times 2006-2019 Pharmacy \& Healthcare Communications, LLC. All Rights Reserved

[5] Food and Drug Administration Circular No. 2014 - 025: Guidelines on the Implementation of New Rules and Regulations and the Licensing of Drugstore/Pharmacy/Botica and Similar Outlets following Administrative Order No. 2014 0034, dated October 13, 2014;

[6] Kanya February 1, 2019, The Importance of Accounting Software for Businesses, How to Manage Accounts Payable Aging Reports

[7] Dennis Najjar, July 11, 2019 The Balance Small Business

[8] Guthman and Dougal, smriti chad, Financial Management: it's Definition, Meaning and Objectives- Discussed! https://www.yourarticlelibrary.com/

[9] Samuel Tabot, The accounts payable management practices of small, medium and micro enterprises in the Cape Metropolis. https://www.researchgate.net/

[10] Varun Mehta, 7 September, 2018, London school of business and finance 